Article

\title{
Theory in Emancipative Action: Aligning Action Research in Information Systems Education with Critical Social Research in Information Systems
}

\author{
Roelien Goede * and Estelle Taylor \\ School for Computer Science and Information Systems, North-West University, Potcefstroom 2520, South Africa \\ * Correspondence: roelien.goede@nwu.ac.za; Tel.: +27-76-543-3188
}

Received: 30 April 2019; Accepted: 16 July 2019; Published: 22 July 2019

\begin{abstract}
As educators, we want to guide our students so that they develop to the best of their ability and are emancipated. As researchers in education, we often use action research. We use proven theories to guide our intervention to emancipate our students. Or do we? Recently, prominent information systems journals have published few papers in the field of information systems education. We demonstrate that the guidelines for action research from a critical social research perspective in information systems are not evident in action research studies in information systems education. The emancipative goals of pure critical social research and reliance on critical social theory to guide our intervention are lacking in these educational studies. Our aim is to provide alignment between educational action research in information systems and information systems research conducted from a critical social theory perspective. Our methodology is to explicitly propose phases of action research from a critical social research perspective, grounded both in information systems and education literature. Then, we demonstrate the value of this approach in a study on the improvement of a data warehousing module. We conclude that by using proven theories and reflecting on the presuppositions in a problem environment, the researcher is able to guide the development of students and the community.
\end{abstract}

Keywords: action research; information systems research; critical social theory; critical systems heuristics; data warehousing education

\section{Introduction}

Our goal as educators is to guide the development of our students. As researchers in a specific discipline (information systems in our case), we want to make a scholarly contribution to the knowledge area and industry. In both our educational and industry-related work, our role is that of an "agent of change", which motivates us to use action research as methodology. However, action research in information systems research has a different emphasis than action research in information systems education research. This paper aims to reflect on and align action research practices in these disciplines.

The principles for conducting critical social theory research in information systems (IS) developed by Myers and Klein [1] have provided scholars in the field of IS with explicit guidance for critical studies. These principles are promoted as a framework for the evaluation of critical social research in IS [2]. Although action research (AR) can be conducted from different ontological and epistemological perspectives, it is often used as research methodology within the critical social research paradigm in IS [3].

We show that even though AR in education has similar critical foundations to critical social theory research, the specific critical features of critical social research as described in IS are not explicitly 
reported in AR studies in IS education (referred to as ISE in this paper). The explicit use of theory and an explicit description of emancipation are absent from the majority of the papers we have reviewed.

The purpose of this paper is to reflect on AR in IS and AR in ISE from a critical social theory perspective to stimulate discourse in the field of ISE on the incorporation of the principles of critical social theory in research projects. Our motivation for aligning AR in ISE with critical social theory AR in IS is fourfold:

1. The target audience of AR in ISE studies can be extended to mainstream IS publications. We could not find publications in the past three years on the education of IS concepts in two of the most popular IS mainstream journals (Management Information Systems Quarterly (MISQ) and European Journal of Information Systems (EJIS)). If studies on ISE reflect the principles for conducting critical social theory research in IS [1], as published in the MISQ and promoted by the editor of EJIS (Rowe, 2012), there might be a higher acceptance rate of such studies. Our claim is supported by the publication of the AR project of Puhakainen and Siponen [4] in MISQ on an AR project on security training. This paper has a strong theoretical underpinning and the intervention is guided by theory;

2. Researchers in IS who use AR may be drawn to extend their research to the education of their specific fields of interests if the guidelines for AR in IS are aligned with ISE research. Gibbs, et al. [5] have substantiated the growing trend in higher education institutions to "break[ing] down the demarcations between traditional scholarship, research and administration/organization";

3. The application of critical social theory assumptions has a strong history in AR in education (as we will indicate in the next section), and AR in IS will benefit from guidelines for critical social theory in AR in education;

4. Intervention as part of AR in IS has a strong theoretical underpinning [6]. By adopting the same focus on theory when conducting AR in ISE, we have an opportunity to equip our students with a knowledge of these theories that they can then use as future IS practitioners.

Our process of aligning AR in IS and AR in ISE is presented in three subsequent sections. In Section 2, we present a discussion of critical social research in these disciplines. This includes a report on recent studies on AR in ISE showing that AR studies in ISE do not explicitly report on the matters identified as principles for critical social theory in IS. Thereafter, in Section 3, we revisit the AR process and propose specific research practices to align critical AR in IS and critical AR in ISE. In Section 4, we report on a study on teaching data warehousing to fourth-year IS students, where our proposal was implemented. We conclude our paper with a reflection on the benefits of explicitly using critical social theory (CST) in AR in ISE.

\section{Theoretical Perspectives on Critical Social Theory Research}

Critical social theory (CST) research developed in reaction to positivistic and interpretive research in the twentieth century. The emancipative ideas of Habermas [7] are often mentioned in discussions on the foundations of current CST research [8-10]. Habermas emphasized the formulation of critical theorems, praxis, and reflection, in the context of the political struggle [7].

The epistemological nature of CST has been expressed by Harvey [11]: Critical social theorists see knowledge as constructed by reflecting on and changing existing sets of oppressive social relations. This can be class, gender, or race oppression. Carr and Kemmis [12] have provided a detailed description of the work of the early critical thinkers in opposition to the positivistic science paradigm in the early 1900 s.

The aim of critical social theory to investigate the underlying assumptions in the problem environment, is echoed in the elements of CST formulated by Harvey [11], summarized in Table 1. The overall purpose of CST is to identify oppressive structures in a problem environment by deconstruction, before eliminating these structures and then reconstructing the situation without 
introducing new oppressive structures. The principles are coded in column one of Table 1 for later reference.

Table 1. Principles for critical social research [11].

\begin{tabular}{|c|c|c|}
\hline Code (ref) & Element & Description \\
\hline $\mathrm{H} 1$ & Abstraction & $\begin{array}{l}\text { Through abstraction, the critical social researcher can reflect on the } \\
\text { deeper problem situation to reveal underlying structures that are } \\
\text { otherwise taken for granted. }\end{array}$ \\
\hline $\mathrm{H} 2$ & Totality & $\begin{array}{l}\text { Totality refers to the view that social phenomena are interrelated } \\
\text { to form a whole. }\end{array}$ \\
\hline $\mathrm{H} 3$ & Essence & $\begin{array}{l}\text { Essence refers to the fundamental element of the } \\
\text { analytical process. }\end{array}$ \\
\hline $\mathrm{H} 4$ & Praxis & $\begin{array}{l}\text { Praxis refers to practical reflective activity to relieve oppression. } \\
\text { Learning takes place through action and reflection. Action is } \\
\text { guided by existing theory. }\end{array}$ \\
\hline H5 & Ideology & $\begin{array}{l}\text { The worldview or Weltanschauung of the participants or } \\
\text { alternatively, the inherent thought processes that guide specific } \\
\text { (oppressive) actions. }\end{array}$ \\
\hline H6 & Structure & The interrelatedness of elements in the problem situations. \\
\hline H7 & History & $\begin{array}{l}\text { "History refers both to the reconstructed account of the past } \\
\text { events and the process by which the reconstruction is made" [11]. }\end{array}$ \\
\hline $\mathrm{H} 8$ & $\begin{array}{l}\text { Deconstruction and } \\
\text { reconstruction }\end{array}$ & $\begin{array}{l}\text { The critical researcher aims to deconstruct the situation into } \\
\text { abstract concepts to study the interrelations between the concepts } \\
\text { with the purpose of discovering the key to the structure of the } \\
\text { situation. The core concept is used to reconstruct the situation. }\end{array}$ \\
\hline
\end{tabular}

\subsection{Action Research in Critical Social Research}

Researchers often use AR as a method independent from a research paradigm. Myers [3] gives examples where AR is used from the different ontological and epistemological perspectives associated with positivism, interpretivism, and CST. Our interest is in CST and thus we will review the literature on IS education in terms of the use of AR and the ontological position of the researchers from a CST perspective in this work.

A method for practicing CST must be able to support the elements of CST listed in the previous section. McTaggart [10] argues in favor of the use of AR in CST to facilitate insight, critique, and transformation. Reflection and transformation should be supported as key activities for the CST researcher [8].

Bradbury-Huang [13] has provided a discussion on criteria for good action research, which we present in Table 2. From a critical social research perspective, it is important to note that Bradbury-Huang [13] refers to the emancipatory nature of action research, the local and wider influence of AR, and the value-driven nature of AR. These traits are all supported by the principles of critical social research in information systems. 
Table 2. Criteria for good action research [13].

\begin{tabular}{cll}
\hline Code (ref) & \multicolumn{1}{c}{ Criteria } & Discussion Quoted from Bradbury-Huang [13] \\
\hline BH1 & Articulation of objectives & $\begin{array}{l}\text { The extent to which authors explicitly address the } \\
\text { objectives they believe relevant to their work and } \\
\text { the choices they have made in meeting those }\end{array}$ \\
\hline BH2 & Partnership and participation & $\begin{array}{l}\text { The extent to and means through which the project } \\
\text { reflects or enacts participative values and concern } \\
\text { for the relational component of research. }\end{array}$ \\
BH3 & $\begin{array}{l}\text { Contribution to action research } \\
\text { theory/practice }\end{array}$ & $\begin{array}{l}\text { The extent to which the project builds on (creates } \\
\text { explicit links with) or contributes to a wider body } \\
\text { of practice knowledge and/or theory that } \\
\text { contributes to the action research literature. }\end{array}$ \\
\hline BH4 & Methods and process & $\begin{array}{l}\text { The extent to which the action research methods } \\
\text { and process are articulated and clarified. }\end{array}$ \\
\hline BH5 & Actionability & $\begin{array}{l}\text { The extent to which the project provides new ideas } \\
\text { that guide action in response to need. }\end{array}$ \\
\hline BH6 & Reflexivity & $\begin{array}{l}\text { The extent to which the authors explicitly locate } \\
\text { themselves as change agents. }\end{array}$ \\
\hline & & $\begin{array}{l}\text { The extent to which the insights in the manuscript } \\
\text { are significant in content and process. By } \\
\text { significant, we mean having meaning and } \\
\text { relevance beyond their immediate context in } \\
\text { support of the flourishing of persons, communities, } \\
\text { and the wider ecology. }\end{array}$ \\
\hline & Significance &
\end{tabular}

\subsection{Action Research and Critical Social Theory in Information Systems}

Before we discuss critical social research in information systems, we will provide a short background on AR in IS and the events prior to the publication of the 2011 paper by Myers and Klein on CST in IS research.

Although action research (AR) has a rich history in many disciplines, it became prominent in IS after the tutorial by Baskerville in 1999. Figure 1 depicts the AR process presented by Baskerville [14], as derived from Susman and Evered [15]. He did not explicitly discuss these phases from a CST research perspective. We discuss the individual phases later in the paper; it is important at this stage to highlight two aspects discussed by Baskerville [14] that may not be clear from the diagram. In the first instance, AR should be seen as facilitating participative change, i.e., in the context of client organization. Secondly, action planning should be guided by theoretical knowledge to distinguish it from consultation and to open up the possibility of scholarly contribution.

The discussion of AR by Baskerville [14] is similar to discussions found in other literature based on the work of Lewin [16], such as the study of McNiff [8].

Baskerville's paper in 1999 was part of a special issue of the prominent journal MISQ on AR. AR was very popular at that stage as it provided academics with an opportunity to apply their trade in industry. A debate started on the scientific nature of AR and prominent scholars, Avison, et al. [17], gave a strong motivation for using theory in IS practice. Although they did not explicitly present their argument from a CST perspective, they promoted values that can be attributed to CST, such as a strong focus on change and reflection, as well as addressing the conflict between espoused and applied theory. They highlighted the need for a framework for conducting AR in IS which, among other characteristics, "specify the tradition and beliefs implied by its [AR] assumptions" [17].

Such a framework was presented by Lau [18], who indeed added an item to the 'assumptions/perspective/tradition' of the researcher, identifying it as "Post positivistic? Theory underlying change should be validated by extent of success in solving the problem" [18]. He explicitly positioned AR in the interpretivist rhetoric of IS. However the balance between theory and practice 
remained a point of scholarly discussion [19]. Other scholars [20,21] have also provided literature reviews of AR studies focusing on the intervention, theory, and post-positivist nature of the research projects.

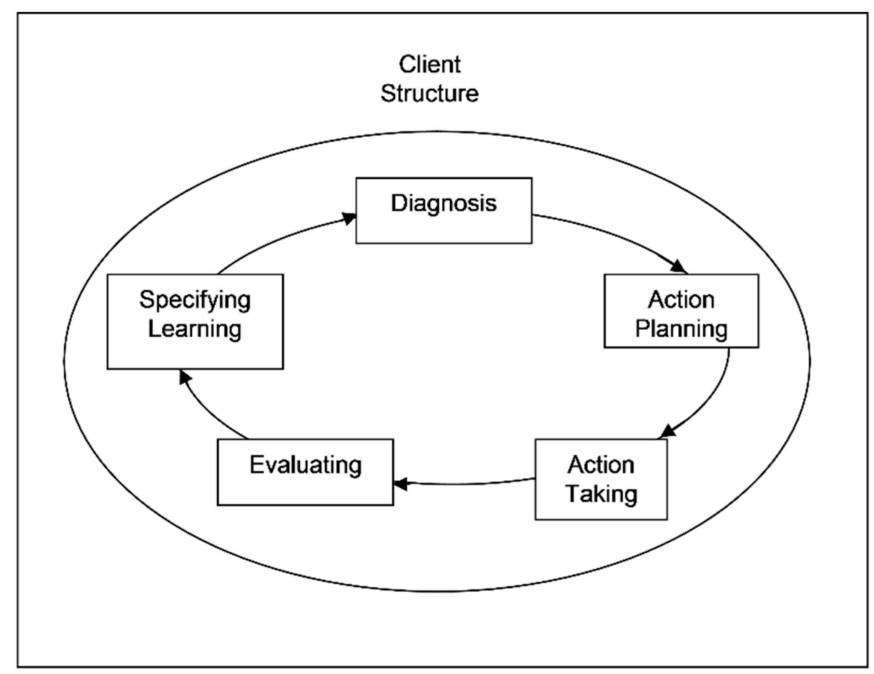

Figure 1. The action research cycle [14].

In reaction to these scholarly issues with AR in IS, Myers and Klein [1] published their paper on the use of CST in IS. In this work, they refer to applications of their ideas in AR and design science research (DSR), since DSR evolved as one of the most prominent approaches in IS at the time. After this publication of Myers and Klein, various AR papers were published in IS, which explicitly used CST as the guiding theory [22,23].

The debate in IS research methodology recently shifted towards issues regarding DSR. The influence of CST in IS is evident in this debate on issues such as values and ethics in research [24]. We conclude this discussion on the context of AR and CST in IS with reference to the tutorial of Wohlin and Aurum [25], who have presented CST as an equally valuable approach in IS to positivistic and interpretive research. They position AR along with DSR and case study research as key methodologies in IS research.

In order to explore the nature of current CST research in IS, we find the principles of Myers and Klein [1] most helpful. They developed the three main elements of CST research, namely insight, critique, and transformation, into principles for CST research (Table 3). 
Table 3. Principles of Critical Social Theory in Information Systems Research [1].

\begin{tabular}{cll}
\hline Code (ref) & \multicolumn{1}{c}{ Principle } & \multicolumn{1}{c}{$\begin{array}{c}\text { Summary of Meaning Quoted from Myers and } \\
\text { Klein [1] }\end{array}$} \\
\hline MK1 & $\begin{array}{l}\text { The principle of using core concepts from } \\
\text { critical social theorists. }\end{array}$ & $\begin{array}{l}\text { Research methods must be guided by the work of } \\
\text { scholars in the field of CST, such as Habermas. }\end{array}$ \\
\hline MK2 & The principle of taking a value position. & $\begin{array}{l}\text { Researchers must articulate their value position, such } \\
\text { as equality or democracy. }\end{array}$ \\
\hline MK3 & $\begin{array}{l}\text { The principle of revealing and challenging } \\
\text { prevailing beliefs and social practices. }\end{array}$ & $\begin{array}{l}\text { The work of CST scholars can be used to highlight } \\
\text { shortcomings of current thinking. }\end{array}$ \\
\hline MK4 & Element: Transformation \\
\hline MK5 & The principle of individual emancipation. & $\begin{array}{l}\text { Intervention should guide self-reflection and } \\
\text { self-transformation to fulfil individual potential. }\end{array}$ \\
\hline MK6 & $\begin{array}{l}\text { The principle of improvements in } \\
\text { social theories. }\end{array}$ & $\begin{array}{l}\text { Transformation of more than the individual is } \\
\text { possible and therefore the society may be improved. }\end{array}$ \\
\hline
\end{tabular}

As indicated in the final element of CST identified by Harvey [11] (H8 in Table 1), CST research is an ongoing process with a pragmatic objective. The CST researcher's task is only completed when emancipation is achieved. This is supported by the cyclic nature of action research. The principles of CST in IS presented here are supportive of the criteria for good AR research listed in Table 2. It should be noted that MK1 (in Table 3) has a wider impact than BH3 (in Table 2) on the contribution of AR. When MK1 is applied to AR, it means that the proposed intervention is guided by the scholarly work of critical social theorists.

\subsection{AR in Education from a Critical Social Theory Perspective: Emancipation and Theory}

We view educational AR, in line with the aims and scope of the Educational AR Journal, as 'AR in educational settings'. We support the definition of educational research of Bassey [26]: “Educational research is systematic, critical and self-critical enquiry which aims to contribute to the advancement of knowledge and wisdom about the experience and nurture of personal and social development towards worthwhile living and the acquisition, development, transmission, conservation, discovery and renewal of worthwhile culture."

Action research is often used in studies by teachers/educators to improve their practices $[27,28]$. Unfortunately, many of these texts are focused on the practices of the method without focusing on its foundations. Action researchers are using systematic and critical enquiry in attempts to improve their practical situation. Improvement and systematic and critical enquiry are used here without a follow-up discussion of exactly what are implied by these terms in the context of scholarly definitions. 'Critical' is not related to the work of critical social theorists. However, the critical social research perspective is evident in the definition of 'educational research' quoted earlier, taken from Bassey [26]. We argue that, traditionally, AR in education has a critical social theory foundation, although it is not explicitly reported in studies, especially those on AR in ISE.

Although change and improvement are often advocated, the term emancipation is not frequently used in literature on AR in ISE. Change is a core characteristic of critical AR research in education. We argue that such 'change' relates to emancipation in critical AR. Kemmis, et al. [29] wrote the following on critical participatory AR: "we ask, "Are the consequences of our practices in some way untoward (irrational, unsustainable, or unjust)?" If we come to the conclusion that the consequences of our practices are in some way untoward, then we know we must make changes in our practices (and to our understandings of our practices, and to the conditions under which we practice) in order to prevent, avoid or ameliorate those untoward consequences" [29]. 
Emancipation is part of the earlier description given of critical AR in Carr and Kemmis [9]. Originally, Carr and Kemmis [9] positioned critical action research in the realm of critical social science: "'Critical social science", then, is the science which serves the "emancipatory" interest in freedom and rational autonomy". However, in the recent book by Kemmis, et al. [29], the term is used only once in the entire book, with this being where the different types of AR are quoted from the book of Carr and Kemmis [12]. We conclude that an explicit focus on emancipation is not against the nature of educational AR studies.

As to the benefits of a more explicit focus on local emancipation, we argue that it gives a tangible objective for the AR project. The AR project is completed when the desired local emancipation is achieved. Additionally, in light of the current focus on the decolonization of education, emphasis is put on the emancipation of the system and the student from their colonial past (see, for example, Battiste [30]). In this paper, we use the term 'emancipation' as it is used in the critical systems thinking literature. Jackson [31] describes emancipation as "bringing about those circumstances in which all individuals could achieve the maximum development of their potential." This definition of emancipation linked to the improvement of individuals is intuitively supportive of the nature of education and may serve as a measure of improvement for educational AR studies.

From a critical social theory perspective, another aspect of AR not reflected in AR in education literature is the role of theory in intervention. There is a more explicit reliance on the work of critical social theorists on the principles for CST in IS (refer MK1 in Table 3) than what is evident in critical AR in ISE research. Once again, this reliance is advocated in critical AR in education [32]. In the practical guide by Reason and Bradbury [33], an entire chapter, written by the educational scholar Kemmis, is devoted to the use of critical social theory in AR [34]. He writes, "In action research and in the social and educational sciences generally, we are normally concerned not solely with practices as the behavior or intentional action of individuals, but also with the ways those practices are socially-constructed and "held in place" by cultural-discursive, social and material economic fields that precede and shape the conduct of practice/praxis." [34]. We conclude that although a review of ISE papers found that an explicit reliance on theory in ISE AR studies is absent, guidance from critical social theory is valued in AR in education.

The role of theory can be different from a participatory action research perspective. Advocates of participatory action research argue that the participants in the project (those involved and affected by the intervention) should take part in all aspects of the intervention and thus also in its planning [10]. Since participants are not always aware of the existing theories, participants are less likely to identify the work of a critical social scholar to guide the intervention, as advised by MK1 in Table 3 (on using the work of critical social theorists).

In arguing the benefits of explicit guidance of critical social theorists in AR intervention, the work of Ulrich [35] is most helpful. Ulrich is a critical social scholar who aims to emancipate those affected by an intervention by incorporating their interests into the decision-making process. He argues that the expert is required to provide a 'guarantor' that ensures that the proposed intervention has a high probability of success. Existing theories and their applicability in a given problem situation may provide such a guarantee based on their previous successes.

From the students' perspective, we argue that the explicit use of theory and awareness of theory will benefit them as a result of the improved success of the intervention described earlier. It will also develop them as scholars in the field. In terms of their role as IS practitioners, they will have a more developed frame of reference to use in their reflection on their practices (in terms of the ideas of Schön [36] on reflective practice). This indeed is one of our key motivations for the proposed alignment of AR in IS and ISE research.

Our final reflection on AR from a critical perspective is on ethics. Gibbs, et al. [5] identify the 'failure to address explicitly the ethical challenges overlooked by existing studies' as a shortcoming in AR in education. This shortcoming can be addressed explicitly by applying the second principle 
of Myers and Klein [1] (refer to Table 3), MK2: the researcher should take a value position on the acceptability and desirability of possible solutions from a normative or ethical perspective.

\subsection{Review on the Use of AR in IS Education Literature}

We studied all papers in the journals Action Research and Educational Action Research from 2010-2018 in order to find AR studies on ISE, but we could not find papers on projects that focus on the formal education of IS concepts. It was decided to expand the study to include AR articles from other journals. Searches were done on Google Scholar and Ebsco Information Services. On Google Scholar, searches were done using the keywords 'action research', 'computer', 'education', 'information', and 'systems' in various combinations, and only articles from 2010 onwards were included. On Ebsco (activating Eric, Academic Search Premier, Applied Science and Technology Source and Library, IS and Technology), searches were done including scholarly (peer reviewed) journal articles from 2010-2019, using similar keywords in various combinations. A more in-depth study of articles identified in this manner showed that only eight of these were AR studies about ISE, with others including topics on the use of computers in education, online education, etc.

We analyzed the eight papers, first in terms of general methodology and second in terms of CST concepts. An analysis of the methodology, goal, theoretical framework, and steps followed can be seen in Table 4.

Table 4. Analysis of the methodology of action research (AR) papers on information systems education (ISE).

\begin{tabular}{|c|c|c|c|}
\hline Paper & Goal & Theoretical Framework & Steps \\
\hline Kapenieks [37] & $\begin{array}{l}\text { To improve selected competencies } \\
\text { that students will need in the future in } \\
\text { information systems (IS) students. }\end{array}$ & $\begin{array}{l}\text { Dewey [38] is stated as } \\
\text { the framework, but } \\
\text { intervention is not } \\
\text { explicitly linked to his } \\
\text { critical aspects. }\end{array}$ & $\begin{array}{l}\text { Three learning cycles: } \\
\text { identification; } \\
\text { construction of living } \\
\text { theory; communication. }\end{array}$ \\
\hline $\begin{array}{l}\text { Jakovljevic and } \\
\text { Ankiewicz [39] }\end{array}$ & $\begin{array}{l}\text { To develop the webpage design skills } \\
\text { of students. }\end{array}$ & $\begin{array}{l}\text { Constructivist learning } \\
\text { theory, various } \\
\text { educational models. }\end{array}$ & $\begin{array}{l}\text { Baskerville [14], depicted } \\
\text { in Figure } 1 .\end{array}$ \\
\hline Jeffrey, et al. [40] & $\begin{array}{l}\text { To identify obstacles to and support } \\
\text { for fostering the development of the } \\
\text { digital information literacy (DIL) of } \\
\text { staff and students in higher education. }\end{array}$ & $\begin{array}{l}\text { Three-step reflective } \\
\text { framework of [41]. }\end{array}$ & $\begin{array}{l}\text { Setting goals, searching } \\
\text { for possible solutions, } \\
\text { critical evaluation, } \\
\text { determining new action. }\end{array}$ \\
\hline Adesemowo, et al. [42] & $\begin{array}{l}\text { To introduce secure e-assessment in } \\
\text { ICT modules on networking. }\end{array}$ & $\begin{array}{l}\text { Blooms taxonomy, } \\
\text { constructivism, } \\
\text { connectivism. }\end{array}$ & $\begin{array}{l}\text { Participatory AR } \\
\text { framework. }\end{array}$ \\
\hline Cochrane [43] & $\begin{array}{l}\text { To extend the use of mobile and Web } \\
2.0 \text { technology in an education } \\
\text { institution's approach to e-learning. }\end{array}$ & $\begin{array}{l}\text { Social constructivist } \\
\text { pedagogies. }\end{array}$ & $\begin{array}{l}\text { Pre-trail, intervention, } \\
\text { post-trial. }\end{array}$ \\
\hline Cuhadar and Kuzu [44] & $\begin{array}{l}\text { To improve interaction through blogs } \\
\text { in an IT course. }\end{array}$ & Constructivism. & $\times$ \\
\hline Esteves, et al. [45] & $\begin{array}{l}\text { To present a framework for teaching } \\
\text { and learning computer programming } \\
\text { within the second life virtual } \\
\text { framework. }\end{array}$ & $\times$ & $\begin{array}{l}\text { Planning, acting, } \\
\text { observing, reflecting. }\end{array}$ \\
\hline Isaias and Issa [46] & $\begin{array}{l}\text { To examine the value of the } \\
\text { communication skills learning process } \\
\text { through various assessments. }\end{array}$ & $\times$ & $\times$ \\
\hline
\end{tabular}

As can be seen in Table 4, the eight articles that indicated that they used action research used different theoretical frameworks. Six of these eight articles followed specific steps. Next, an analysis of CST concepts was conducted for the eight papers using AR. The results can be seen in Table 5. 
Table 5. Analysis of papers according to critical social theory (CST) concepts.

\begin{tabular}{|c|c|c|c|c|c|c|c|c|c|}
\hline & Transformation & Insight & Critique & $\begin{array}{l}\text { Using Core } \\
\text { Concepts from } \\
\text { Critical Social } \\
\text { Theorists (MK1) }\end{array}$ & $\begin{array}{l}\text { Taking a } \\
\text { Value } \\
\text { Position } \\
\text { (MK2) }\end{array}$ & $\begin{array}{c}\text { Revealing and } \\
\text { Challenging } \\
\text { Prevailing Beliefs } \\
\text { and Social } \\
\text { Practices (MK3) }\end{array}$ & $\begin{array}{l}\text { Individual } \\
\text { Emancipation } \\
\quad \text { (MK4) }\end{array}$ & $\begin{array}{l}\text { Improvements } \\
\text { in Society } \\
\text { (MK5) }\end{array}$ & $\begin{array}{c}\text { Improvements } \\
\text { in Social } \\
\text { Theories } \\
\text { (MK6) }\end{array}$ \\
\hline Kapenieks [37] & $\begin{array}{l}\text { Enhancing essential competencies of } \\
\text { information systems (IS) students. }\end{array}$ & $\checkmark$ & $\checkmark$ & $x$ & $\checkmark$ & $\checkmark$ & $\checkmark$ & $\checkmark$ & $x$ \\
\hline Jakovljevic and Ankiewicz [39] & Improving the web design skills of students. & $\checkmark$ & $x$ & $x$ & $x$ & $\checkmark$ & $\checkmark$ & $\checkmark$ & $x$ \\
\hline Jeffrey, et al. [40] & $\begin{array}{l}\text { Empowering participants. Reducing obstacles. } \\
\text { New approaches to learning and personal } \\
\text { growth in digital information literacy (DIL). }\end{array}$ & $\checkmark$ & $\checkmark$ & $x$ & $\checkmark$ & $\checkmark$ & $\checkmark$ & $\checkmark$ & $x$ \\
\hline Cochrane [43] & $\begin{array}{l}\text { Developing the international community of } \\
\text { practice model for supporting new technology } \\
\text { integration, development, and change. }\end{array}$ & $\checkmark$ & $x$ & $x$ & $x$ & $x$ & $\checkmark$ & $\checkmark$ & $x$ \\
\hline Adesemowo, et al. [42] & $\begin{array}{l}\text { Introduction of secure e-assessment in ICT } \\
\text { modules on networking. }\end{array}$ & $\checkmark$ & $\checkmark$ & $x$ & $\checkmark$ & $x$ & $\checkmark$ & $\checkmark$ & $x$ \\
\hline Cuhadar and Kuzu [44] & Improving instruction and social interaction. & $\checkmark$ & $x$ & $x$ & $x$ & $x$ & $\checkmark$ & $\checkmark$ & $x$ \\
\hline Esteves, et al. [45] & $\begin{array}{l}\text { Improving effectiveness in the learning of } \\
\text { programming. }\end{array}$ & $\checkmark$ & $x$ & $x$ & $x$ & $x$ & $\checkmark$ & $\checkmark$ & $x$ \\
\hline Isaias and Issa [46] & $\begin{array}{l}\text { Promoting communication skills and boosting } \\
\text { self-esteem. }\end{array}$ & $\checkmark$ & $x$ & $x$ & $x$ & $x$ & $\checkmark$ & $\checkmark$ & $x$ \\
\hline
\end{tabular}


As can be seen in Table 5, three of the articles [37,40,42] had all the elements of critical research, namely insight, critique, and transformation. None explicitly referred to the six principles of critical social research [1], but two [37,40] applied four of these principles, two papers [39,42] applied three of these principles, and the others applied two of these principles. None of the articles used core concepts from critical social theorists (MK1). Only three of them clearly took a value position (MK2). Three papers explicitly reported on prevailing beliefs and social practices (MK3).

All papers implicitly applied the concepts of individual emancipation (MK4) and improvement in society (MK5). The term emancipation was not explicitly used in any of the papers. None of them reflected on their contribution to the improvement of social theories (MK6).

The analysis of these journal papers indicated that action is not often guided by the scholarly work of critical social scholars. Having presented the background on CST in IS and ISE, as well as on the nature of AR, we are now ready to propose practices that align AR in ISE and CST in IS.

\section{Action Research from a Critical Social Perspective}

The purpose of this third section of the paper is to link the principles described previously to the AR phases in order to demonstrate how AR can be used effectively as a method for CST in ISE. Throughout the paper, we refer to the element $i$ of Harvey [11] as H $i$ (refer to Table 1), principle $i$ of Myers and Klein [1] as MK $i$ (refer to Table 2), and criterion $i$ of Bradbury-Huang [13] as BH $i$ (refer to Table 3). We thus request the reader to keep Tables 1-3 at hand when reading this section.

\subsection{The FMA Model for Action Research}

Before we begin to discuss the AR phases individually, we want to provide another perspective on AR. As noted in the discussion of Figure 1 in Section 2, the planned intervention of AR is guided by theoretical knowledge, although not explicitly indicated in that figure. Checkland and Holwell [47] have provided an alternative depiction of the AR process, which they used to develop their 'soft systems methodology (SSM)'. Their model is referred to as the Framework, Methodology and Application (FMA) model for AR, and is shown in Figure 2.

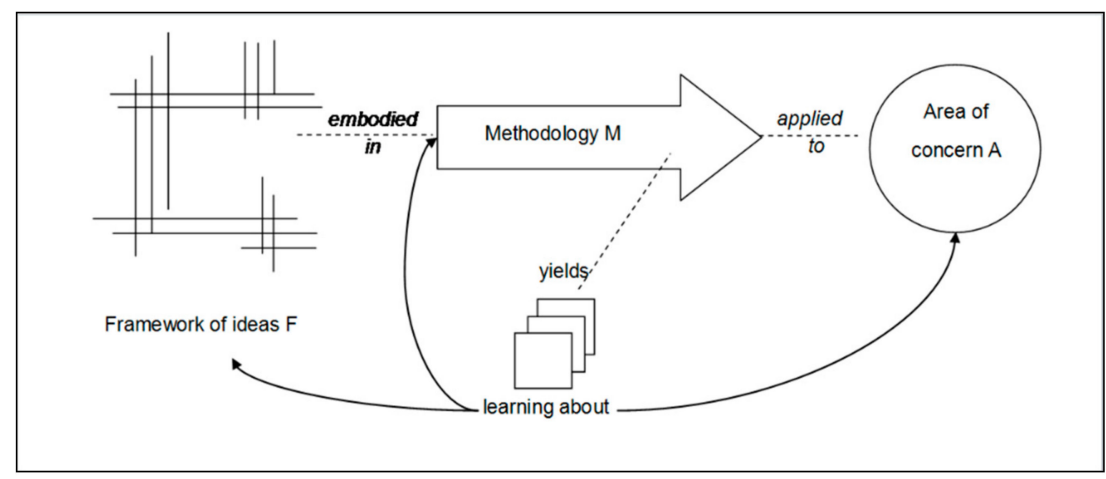

Figure 2. The FMA model of Checkland and Holwell [47].

The FMA model describes the framework of ideas $\left({ }^{\prime} \mathrm{F}^{\prime}\right)$ that is embodied in a methodology $\left({ }^{\prime} \mathrm{M}^{\prime}\right)$, which is applied to an area of concern ('A'). Learning takes place on all three of these levels. This depiction shows clearly that action is guided by ' $\mathrm{F}^{\prime}$, which corresponds to MK1 on the ideas of critical scholars. The 'Learning about' arrow also stretches back to ' $F^{\prime}$, which corresponds to MK6 on making a contribution or improvement in social theories. From their discussion of the model and the development of SSM by Checkland and Holwell [47], it is clear that ' $\mathrm{A}$ ' represents various cases or instances and that ' $\mathrm{M}$ ' (SSM in their case) was refined after each application. This indicates an attempt to 'generalize' SSM so that it is applicable to more problem situations. This corresponds to MK5 on improvement of the society. Each application of ' $\mathrm{M}$ ' to a specific ' $\mathrm{A}$ ' relates to an individual. 


\subsection{A CST Perspective on the Phases of AR}

This section revisits the phases of AR [14] given in Figure 1 from a CST perspective. We present our proposal on the explicit practices in AR from a CST perspective in a table (Table 6) to be able to link our proposal to the principles presented in Tables 1-3 in Section 2 of the paper on theoretical perspectives.

Table 6. Proposal for the explicit use of critical social theory in action research.

\begin{tabular}{|c|c|c|c|}
\hline \multicolumn{4}{|c|}{ Description of AR Phases from a Critical Social Perspective Sensitive to Indicated Theoretical Frameworks. } \\
\hline \multicolumn{4}{|c|}{ Phase 1: Diagnosis } \\
\hline \multicolumn{4}{|c|}{$\begin{array}{l}\text { The aim of the diagnosis phase is to better understand the problem situation. From a CST perspective, this is the most important } \\
\text { phase of the process. It is during this stage that the problem situation is deconstructed to identify oppressing structures. Care should } \\
\text { be taken to understand the history and historical context of the situation. } \\
\text { During diagnosis, the essence of the situation must be disclosed in the wider context of the problem environment and stakeholders. } \\
\text { Churchman [48], another scholar in the critical tradition, argues that a holistic view (such as his systems approach) should identify } \\
\text { the real objective of the situation, i.e., the objective that will not be sacrificed when priorities are set. This also relates to the 'essence'. } \\
\text { Reflection is part of diagnosis, which ties to abstraction to identify oppressing structures and worldviews present. Critical systems } \\
\text { heuristics, developed by Ulrich [35], can be used to facilitate the process of abstraction and reflection, as shown in Section } 4 \text {. }\end{array}$} \\
\hline \multicolumn{4}{|c|}{ Applicable Principles from Theory } \\
\hline $\begin{array}{c}\text { FMA Framework of } \\
\text { Checkland and Holwell [47]: } \\
\text { Refer to Figure } 2\end{array}$ & $\begin{array}{l}\text { Element Hi of Harvey [11]: } \\
\text { Refer to Table } 1\end{array}$ & $\begin{array}{l}\text { Principle MKi of Myers and } \\
\text { Klein [1]: Refer to Table } 2\end{array}$ & $\begin{array}{c}\text { Criterion BHi of } \\
\text { Bradbury-Huang [13]: } \\
\text { Refer to Table } 3\end{array}$ \\
\hline $\begin{array}{l}\text { F: Framework for } \\
\text { understanding; } \\
\text { A: Specific problem area } \\
\text { learning about (reflection). }\end{array}$ & $\begin{array}{l}\text { H1: Abstraction } \\
\text { H6: Structure; } \\
\text { H7: Historical context; } \\
\text { H3: Essence; } \\
\text { H2: Totality; } \\
\text { H5: Ideology; } \\
\text { H8: Deconstruction. }\end{array}$ & $\begin{array}{l}\text { MK1: Critical social theorists; } \\
\text { MK3: Prevailing beliefs. }\end{array}$ & $\begin{array}{l}\text { BH1: Objectives; } \\
\text { BH2: Participants. }\end{array}$ \\
\hline
\end{tabular}

Phase 2: Action Planning

After the problem is understood and the oppressive structures have been identified, the CST action researcher finds appropriate and theoretical sound strategies to apply to the situation to facilitate the emancipation.

Clear objectives for the intervention should be stated. In the CSH of Ulrich [35], the idea is to emancipate those affected by using strategies that are proven. He refers to the idea of a 'guarantor' - some proof that the expert has reason to believe that the proposed intervention will be successful in relieving the oppressive structures identified in the previous phase.

Key to action planning in CST is to understand that methods are based on certain assumptions. The CST researcher should take responsibility to understand these assumptions and evaluate the applicability of the proposed methods in the problem environment. The context of the problem situation should be taken into account, as promoted by Baskerville [14]. Focus should be on participative change rather than consultation.

The participants should also take ownership of the action plan, rather than only the researcher. According to Ulrich [35], the power relation must be in favor of those 'affected' and not the 'experts'.

The result of the action planning phase should be an action plan that clearly indicates how the interests of the oppressed will be served by the proposed action and a substantiation that the proposed intervention is likely to succeed.

\begin{tabular}{|c|c|c|c|}
\hline \multicolumn{4}{|c|}{ Applicable Principles from Theory } \\
\hline $\begin{array}{c}\text { FMA Framework of } \\
\text { Checkland and Holwell [47]: } \\
\text { Refer to Figure } 2\end{array}$ & $\begin{array}{l}\text { Element Hi of Harvey [11]: } \\
\text { Refer to Table } 1\end{array}$ & $\begin{array}{l}\text { Principle MKi of Myers and } \\
\text { Klein [1]: Refer to Table } 2\end{array}$ & $\begin{array}{l}\text { Criterion BHi of } \\
\text { Bradbury-Huang [13]: } \\
\text { Refer to Table } 3\end{array}$ \\
\hline $\begin{array}{l}\text { ' } \mathrm{M} \text { ' is the intervention that is } \\
\text { applied to the problem ' } \mathrm{A} \text { '. } \\
\text { The intervention should be } \\
\text { informed by ' } \mathrm{F} \text { ' in such a way } \\
\text { that reflection on its } \\
\text { application assists reflection } \\
\text { on ' } \mathrm{M} \text { ', but also on ' } \mathrm{F} \text { ' and 'A'. } \\
\text { Various social theories have } \\
\text { been used to guide action in IS, } \\
\text { including actor-network } \\
\text { theory [49] and structuration } \\
\text { theory [50] in IS. Basden [51] } \\
\text { shows how the work of } \\
\text { Dooyeweerd [52] is useful to } \\
\text { guide action in IS. }\end{array}$ & $\begin{array}{l}\text { H4: Praxis; } \\
\text { H2: Totality. }\end{array}$ & $\begin{array}{l}\text { MK1: Critical social theorists: } \\
\text { Ulrich [35]; } \\
\text { MK6: Improvements in social } \\
\text { theories; } \\
\text { Various social theories have } \\
\text { been used to guide action in IS, } \\
\text { including actor-network } \\
\text { theory [49] and structuration } \\
\text { theory [50] in IS. Basden [51] } \\
\text { shows how the work of } \\
\text { Dooyeweerd [52] is useful to } \\
\text { guide action in IS. }\end{array}$ & $\begin{array}{l}\text { BH1: Objectives; } \\
\text { BH4: Methods and processes; } \\
\text { BH7: Significance; } \\
\text { BH5: Actionability; } \\
\text { BH6: Reflexivity; } \\
\text { BH2: Participants. }\end{array}$ \\
\hline
\end{tabular}


Table 6. Cont.

\begin{tabular}{|c|c|c|c|}
\hline \multicolumn{4}{|c|}{ Description of AR Phases from a Critical Social Perspective Sensitive to Indicated Theoretical Frameworks. } \\
\hline \multicolumn{4}{|c|}{$\begin{array}{l}\text { Phase 3: Action Taking } \\
\text { In this phase, the plan is executed. It is in this phase where individual emancipation and eventually improvement of society are } \\
\text { achieved. Ulrich [35] focuses the attention on 'witnesses' of the affected, i.e., representatives of the oppressed in the process of } \\
\text { intervention. Baskerville's [14] idea of participative change in the context of the client may facilitate this as long as it is done from a } \\
\text { critical perspective, which has the interests of the oppressed in mind. In terms if our stance on emancipation, the goal of action taking } \\
\text { in ISE is to ensure that students develop to their full potential. }\end{array}$} \\
\hline \multicolumn{4}{|c|}{ Applicable Principles from Theory } \\
\hline $\begin{array}{c}\text { FMA Framework of } \\
\text { Checkland and Holwell [47]: } \\
\text { Refer to Figure } 2\end{array}$ & $\begin{array}{l}\text { Element Hi of Harvey [11]: } \\
\text { Refer to Table } 1\end{array}$ & $\begin{array}{l}\text { Principle MKi of Myers and } \\
\text { Klein [1]: Refer to Table } 2\end{array}$ & $\begin{array}{l}\text { Criterion BHi of } \\
\text { Bradbury-Huang [13]: } \\
\text { Refer to Table } 3\end{array}$ \\
\hline Performing ' $\mathrm{M}^{\prime}$ in ' $\mathrm{A}$ '. & $\begin{array}{l}\text { H4: Praxis; } \\
\text { H8: Reconstruction. }\end{array}$ & $\begin{array}{l}\text { MK4: Individual } \\
\text { emancipation; } \\
\text { MK5: Improvements to } \\
\text { society. }\end{array}$ & $\begin{array}{l}\text { BH5: Actionability; } \\
\text { BH2: Participants. }\end{array}$ \\
\hline
\end{tabular}

Phase 4: Evaluation of Success

The aim of this phase is to evaluate the success of the intervention. From a CST perspective, this evaluation has a strong pragmatic character as the main measure of success is the individual (or group emancipation required, as identified during the diagnosis phase). Data collection and analysis methods of other paradigms are often used to demonstrate or understand the effects of the intervention. A CST researcher will take care to analyse the totality of the situation to ensure that unintended consequences are identified and that they do not create new oppressive structures. This is a longer-term view than is typical of most research projects.

Once again, we urge the CST researcher to investigate the assumptions inherent to specific research methods to ensure validity and integrity.

\begin{tabular}{|c|c|c|c|}
\hline \multicolumn{4}{|c|}{ Applicable Principles from Theory } \\
\hline $\begin{array}{c}\text { FMA Framework of } \\
\text { Checkland and Holwell [47]: } \\
\text { Refer to Figure } 2\end{array}$ & $\begin{array}{l}\text { Element Hi of Harvey [11]: } \\
\text { Refer to Table } 1\end{array}$ & $\begin{array}{l}\text { Principle MKi of Myers and } \\
\text { Klein [1]: Refer to Table } 2\end{array}$ & $\begin{array}{c}\text { Criterion BHi of } \\
\text { Bradbury-Huang [13]: } \\
\text { Refer to Table } 3\end{array}$ \\
\hline Mostly in 'A'. & $\begin{array}{l}\text { H7: Historical; } \\
\text { H2: Totality; } \\
\text { H8: Reconstruction. }\end{array}$ & $\begin{array}{l}\text { MK4: Individual } \\
\text { emancipation; } \\
\text { MK5: Improvements to } \\
\text { society. }\end{array}$ & $\begin{array}{l}\text { BH7: Significance (long term); } \\
\text { BH4: Methods and processes. }\end{array}$ \\
\hline \multicolumn{4}{|c|}{$\begin{array}{l}\text { In both the model of Baskerville (1999) and the FMA model, AR wants to achieve more than only individual emancipation. It is in } \\
\text { this phase where the difference between consultation and AR is most evident. The consultant moves on to a new 'A', while the AR } \\
\text { researcher tries to formulate abstractions or generalization of the experience to benefit the society and the scholarly society. The role } \\
\text { of the researcher must be also reflected upon. }\end{array}$} \\
\hline \multicolumn{4}{|c|}{ Applicable Principles from Theory } \\
\hline $\begin{array}{c}\text { FMA Framework of } \\
\text { Checkland and Holwell [47]: } \\
\text { Refer to Figure } 2\end{array}$ & $\begin{array}{l}\text { Element Hi of Harvey [11]: } \\
\text { Refer to Table } 1\end{array}$ & $\begin{array}{l}\text { Principle MKi of Myers and } \\
\text { Klein [1]: Refer to Table } 2\end{array}$ & $\begin{array}{l}\text { Criterion BHi of } \\
\text { Bradbury-Huang [13]: } \\
\text { Refer to Table } 3\end{array}$ \\
\hline $\begin{array}{l}\text { The CST researcher reflects not } \\
\text { only on the emancipation in } \\
\text { 'A', but also on his/her } \\
\text { intervention ' } \mathrm{M} \text { ' and the ' } \mathrm{F} \text { ' } \\
\text { framework of ideas used to } \\
\text { plan the intervention. }\end{array}$ & H1: Abstraction. & $\begin{array}{l}\text { MK4: Individual } \\
\text { emancipation; } \\
\text { MK5: Improvements to } \\
\text { society; } \\
\text { MK6: Improvements in social } \\
\text { theories. }\end{array}$ & $\begin{array}{l}\text { BH7: Significance (long term); } \\
\text { BH6: Reflexivity. }\end{array}$ \\
\hline
\end{tabular}

As $A R$ is a cyclic process, the entire cycle may be repeated again to ensure that emancipation was achieved. In the next section, we demonstrate these ideas in a research project on information systems education.

\section{Illustrative Case Study}

In this section, we add a condensed report on an AR project from a critical social perspective to demonstrate the ideas presented in the previous sections. We once again add references to principles in brackets to link our work to the theoretical part of the paper. Again, we request the reader to keep Tables 1-3 and Table 6 at hand when reading this section. The aim of our project was to improve the ability of fourth-year information systems students to contribute to industry after completion of a module on data warehousing by redesigning the module (BH1).

Since this research is done in an educational setting (fourth year of an IT degree at a university) and is aimed at improvement of the situation based on critical and systematic evaluation as described 
by the definition of educational research provided earlier (of Bassey [26]), it is presented as an example of an 'educational action research study'.

\subsection{Background and Research Methodology}

Students of information systems are highly sought after in the information systems industry in South Africa. Their academic preparation, however, lacks industry exposure and they are often 're-trained' in industry. In the short term, this prevents them from contributing to the organization paying their salary.

The FMA framework presented in Figure 3 provides an overview of our project. We used CSH of the critical scholar Werner Ulrich [35] as guidance for our reflection and emancipation (MK1). Our area of concern ('A') was higher education in data warehousing and specifically our own (BH2 and BH6) students who are busy with their fourth and final year in information systems. We aimed to improve their ability to contribute to industry by developing a new instructional design ('M') based on the principles of project-based learning (PBL). The development of the instructional design was aimed at the emancipation of our students (reaching potential) and this process was guided by CSH developed by Ulrich [35].

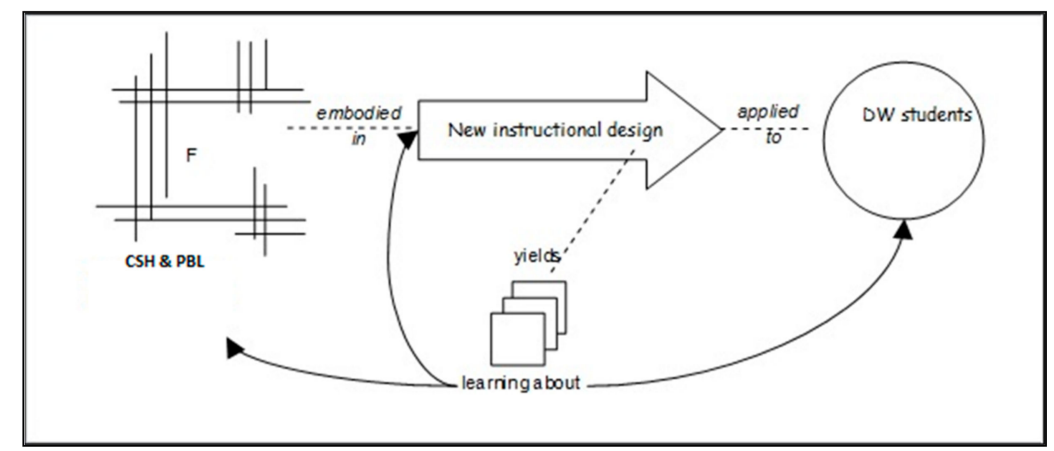

Figure 3. Application of FMA model.

We first give a short summary of critical social heuristics (CSH) and PBL learning, as these served as the framework of understanding in our project.

\subsection{Guiding Literature}

Any research report on AR from a CST perspective as advocated in this paper requires a literature review on the framework of ideas that guided the intervention (MK1 and BH4).

\subsubsection{Critical Systems Heuristics}

Critical social heuristics (CSH) is a methodology employed to practice critical systems thinking, which is a strand of systems thinking. Systems thinking promotes holistic thinking about problem situations in terms of systems, which we view as sets of interrelated elements (in accordance with Ackoff [53]). Critical systems thinkers focus on inequalities in reality. Critical systems thinking has the same ideological roots as critical social research. Ulrich [35] motivates 'critical' as both emancipative and reflective- - he argues that one must review their own position and that of other involved parties in terms of assumptions in order to understand how affected parties are oppressed and how their position can be elevated from 'affected' to 'involved'. He formulated 12 questions that should be answered for the present state ('what is?') and the future state ('what should?') to enable the facilitator to identify different positions in a problem environment. Only when the underlying assumptions are brought to light can the oppressed be emancipated. We used the CSH boundary questions to understand the positions of the students, lecturers, and industry professionals in our project (BH2). 


\subsubsection{Project-Based Learning}

We support the definition of Thomas [54], who describes project-based learning (PBL) as a model where learning is organized around complex tasks based on challenging questions or problems; students are involved in design, problem-solving, decision-making, and investigative activities; students work relatively autonomously over extended periods of time; and learning culminates in realistic products or presentations. Helle, et al. [55] have provided a detailed discussion of PBL.PBL has many advantages, such as getting students to work with teammates to apply concepts in order to solve real-world problems, a focus on deep-learning and critical thinking, a better understanding, and the development of technical skills [55].

We are now ready to present our project according to the phases of AR, with explicit reference to the principles of CST discussed earlier.

\subsection{Diagnosis Phase}

The essence of the problem should be understood (H3). Why does industry feel they need to retrain graduates? This raises a number of different questions, such as, Where does the 'real' problem lie-industry, lecturers, or students? Can the problems be addressed in one module in the fourth year? Should industry be involved in the solution?

A diagnosis guided by $\mathrm{H} 1, \mathrm{H} 2, \mathrm{H} 5, \mathrm{H} 6$, and $\mathrm{MK} 3$ opened up many more questions on the history and scope of the problem. The work of Ulrich [35] guided a discussion on who the involved and affected parties are in this problem environment (MK1). How can we involve students and industry in a process normally controlled by the university (BH2)?

The ideas of Churchman [48] on the 'real' objective stimulated a discussion on the 'real' objectives of all the concerned parties, such as, Are the students motivated by grades or by knowledge? Is it possible for industry to understand the commitments of universities to students in terms of scholarly preparation for post-graduate studies? Are lecturers willing, able, and free to commit to being up-to-date with the technology used by industry? Which sacrifices are the parties willing to make to better prepare students for industry?

Part of the diagnosis phase is to identify the oppressing structures. In this case, it can also be combined with 'taking a value position' (MK2). Our view was that the students, industry, and lecturers all experience some oppression. The students are disadvantaged because they have expectations of good employment after their studies. They receive a small salary and are re-trained by industry after four years at university. Industry is disadvantaged because they pay taxes to the government to develop universities to train future staff. Due to this, they have to pay students while spending all the money and taking an unproductive amount of time to retrain them. Lecturers are disadvantaged as they are expected to market the university by delivering industry-ready students while producing good quality postgraduate students, all while producing scholarly output in terms of good publications.

\subsection{Action Planning}

CSH was used to allow industry, lecturers, and students the opportunity to formulate their views (BH2). The researchers and lecturers (BH6) facilitated this process. We reformulated the questions to link them explicitly to the module on data warehousing (DW). Two experienced industry professionals were asked to complete the 12 questions of CSH. They gave complete answers and had similar ideas on student preparation. Eleven students participated, of which three had industry experience. The small number of students who participated may be seen as a possible limitation of this case study. Unfortunately, these postgraduate classes tend to have a small number of students. The proposed method, however, is not compromised by the small number of participants. Two lecturers were asked to reflect on the $\mathrm{CSH}$ questions. The analysis of the responses was conducted by interpretive content analysis (BH4). This is an indication of the pluralistic nature of CST research. We used content analysis to compare the responses to the 12 questions and created a summary table with the answers of the 
specific interest groups (BH4). The full table is outside the scope of this paper (see footnote 1). As a demonstration, we present the answer to one question in Table 7.

Table 7. Summary of responses to critical social heuristics (CSH) questions.

\begin{tabular}{|c|c|c|c|}
\hline Question & Student & University & Industry \\
\hline $\begin{array}{l}\text { What ought to be the purpose } \\
\text { of the system (S); i.e., what } \\
\text { goal stated ought } S \text { be able to } \\
\text { achieve to serve the client? }\end{array}$ & $\begin{array}{l}\text { To enlighten learners } \\
\text { about what is done with } \\
\text { the data after it has been } \\
\text { collected, because the } \\
\text { data warehousing (DW) } \\
\text { module expands on the } \\
\text { knowledge of databases. }\end{array}$ & $\begin{array}{l}\text { To prepare students to } \\
\text { contribute to industry and } \\
\text { successfully design DW and to } \\
\text { work in groups, to self-direct, } \\
\text { and to become a life-long } \\
\text { learner. }\end{array}$ & $\begin{array}{l}\text { To teach future project } \\
\text { managers how to report } \\
\text { on the business or } \\
\text { enterprise in its entirety. }\end{array}$ \\
\hline
\end{tabular}

The overwhelming finding of the analysis of the CSH data was that the students must be guided to do a realistic industry-type project on data warehousing with input from data warehouse industry professionals (BH1 and BH5). The scope of the project and the available guidance should enable the students to spend a fair amount of time on the project while completing their other modules (BH1 and $\mathrm{BH} 5)$.

In terms of the FMA model, it was decided to develop an instructional design ('M') based on PBL principles for the module on data warehousing (BH1 and BH4). The guarantor in terms of Ulrich [35] was the fact that PBL has been used effectively in other situations and that the industry professionals were willing to be involved in the design and in the evaluation of students.

\subsection{Action Taking}

A complete discussion of the instructional design is outside the scope of this paper. Care was taken to develop guidelines for the selection of a suitable project (BH5). The instructional design included separate sections on methodological data warehouse knowledge and practical data warehousing knowledge (BH5). Many of the needs of the university in terms of the scholarly developments of students were addressed in the methodological knowledge section. Students are expected to demonstrate high-level academic skills in written assignments, such as evaluation, analysis, and critical thinking. The needs of industry were addressed in the practical project. Data was provided to the students from two different source systems and they had to develop a data warehouse that satisfied specific user requirements.

In terms of assessment, students were given rubrics used to evaluate their data warehouses. The effort taken by the students to solve their own problems was investigated by means of interviews. Students had to develop artefacts (software and documentation) according to standards found in the data warehousing industry. They worked in groups and were assessed in terms of their project management skills and teamwork. Teamwork, creation of artefacts, and creative problem solving are all cornerstones of PBL (BH4 and BH5).

\subsection{Evaluating Success}

The evaluation of the success of an intervention in CST can be viewed as a pragmatic process: did the required intervention take place? In this case, it is difficult to measure since one has to follow the students for a longer period to know if they were beneficial in the organization that appointed them.

We decided to conduct interpretive interviews with students to understand the impact of the module on their other modules and to understand their experience of the module in terms of their perception on readiness for industry. Students responded very positively to the industry nature of the project. They reported time management issues. Their main concern, which is very valid, was that their knowledge of the project as a whole was very limited when they started. Their methodological knowledge developed in parallel with their practical knowledge and they did not understand future problems and implications when solving current problems. 
The lecturers expressed a feeling of self-actualization after the project as they guided the students to do work that they themselves had never done before. The nature of PBL does not require lecturers to give technical guidance for every problem encountered by the students. They facilitated group learning and students assisted one another in solving technical problems.

The involved industry professionals were surprised by the creativity of the students and did recruit some of them. The industry professionals did experience difficulty fulfilling their commitments in terms of time to the university. They also expressed the need for future collaboration.

Although many of the emancipative goals of the project (MK4, MK5) were achieved, the concern raised by the students regarding holistic understanding of the project should be addressed in the next iteration of the AR project.

\subsection{Specifying Learning}

The 'specifying learning' phase of AR forms a vehicle for the scholarly reflection represented by MK4, MK 5, and MK6 and the 'learning about' concept of the FMA framework of Checkland and Holwell [47].

In terms of reflection ' $\mathrm{F}$ ', we have learnt that although Ulrich [35] developed CSH in a planning environment aimed at representing the fears of citizens, it is usable and very useful for representing the views of students in an educational environment. We believe the focus on polemical reasoning rather than rational reasoning promoted by Ulrich [35] makes this possible (MK6). Students are not required to prove their case. It is the responsibility of the lecturers to step back and rationally consider and formulate the case presented by the students.

The theoretical description of PBL proved very helpful in the development of the instructional design. The problem concerning the holistic view of the solution raised by the students is not documented and we aim to make a contribution towards PBL after further investigation (BH5).

In terms of reflection on ' $\mathrm{M}$ ', we feel that our newly developed instructional design can be used to the advantage of many other modules in information systems/technology programmes and is not limited to data warehousing. We set an example at our university of how to redesign a module in order to better prepare students for industry, while still developing their skills as scholars in the field of information technology (BH5).

We believe that we did benefit the society (MK5), since our students now need less retraining by industry and are able to contribute to problem solving initiatives undertaken by industry, to the benefit of society.

Finally, we reflect on the students as part ' $A$ '. After our evaluation interviews, we have reason to state that our students did experience individual emancipation (MK4). They enjoyed the 'real work'-nature of the project and developed confidence in their ability to start their careers as IT professionals. With their help, we were able to identify the stated shortcoming and we are considering changes to the instructional design to alleviate the problem. In terms of industry emancipation, we have received positive feedback from the employers of two of the students who completed the module. An employer wrote, "They are both very pleasant consultants and we are extremely happy to have them on our Consulting Team". Another employer wrote, "With [your university] graduates, they generally miss the graduation program, and get hired full-time from the word go." Such reactions from employers show that our intervention is indeed improving the situation of industry as a stakeholder.

\section{Conclusions}

When practicing AR from a CST research perspective, the researcher is empowered to make improvements in the problem environment. The researcher should take the responsibility associated with the opportunity. The principles of Harvey [11], Myers and Klein [1], and Bradbury-Huang [13] provide guidelines for good CST research and the reporting thereof, as presented in Section 2.

After our review of the literature on studies in ISE, we concluded that although AR is used in the field of IS education, very few authors write their reports explicitly from a critical social theory 
perspective and none have explicitly referred to the principles of good CST research. Our aim was therefore to align action research from a CST perspective in IS with AR in ISE to achieve the advantages stated in the introduction.

We described, in Section 3, how the stated principles can be explicitly incorporated in the phases of AR to benefit all of the involved and affected parties in ISE research. Key to the application of CST in AR is the use of existing theory to guide intervention. This theory can originate from scholars in CST, such as Habermas or Ulrich, or it can be from another paradigm applied from a CST perspective, as we have done with PBL. From a CST perspective, researchers are required to study the assumptions of the selected theories carefully to justify their application in the relevant problem environment.

In Section 4, we illustrated our ideas in an example study. We selected CSH since it focusses on the role of the affected and it provides a method for stakeholders to articulate their assumptions about the problem environment. After we identified the need to simulate industry projects in our module, we selected PBL as a second guiding theory, since it provides principles for using projects in education. This case study must be repeated every year to ensure that we update our approach regularly for the full benefit of all our students. The conclusions of our case study are given as part of the specifying learning phase of the AR project.

When researchers in ISE use AR explicitly from a CST perspective, as described in Table 6, their research will typically:

- explicitly state the emancipative goals of their research to guide students to develop to their full potential;

- explicitly state a value position, in terms of what they believe is best for all involved and affected;

- explicitly reflect on their own assumptions and prevailing beliefs, i.e., their value position;

- use CST theories with a proven track record to guide emancipative change;

- make a contribution to CST;

- make a contribution to the scholarly fields of ISE and IS and AR; while

- benefitting their students and the larger community.

Using guidelines from this study may improve the acceptance rate of AR in ISE studies in mainstream IS publications. Furthermore, aligning the guidelines for AR in IS with ISE research may encourage IS researchers to conducted research on the education of their specific fields of interests. From the students' perspective, we argue that the explicit use of theory and awareness of theory will benefit them as a result of the improved success of the intervention described earlier. It will also develop them as scholars in the field. In terms of their role as IS practitioners, they will have a more developed frame of reference to use in their reflection on their practices. This research may also have an impact on ethics by applying the second principle of Myers and Klein, indicating that the researcher should take a value position on the acceptability and desirability of possible solutions from a normative or ethical perspective.

The "critical" researcher should reflect on his/her own assumptions, as well as the inherent assumptions of the methods used for enquiry. The FMA model (presented in Figure 1 in Section 2) also holds true for commonly used research methods. Methods and methodologies which are applied in a problem environment are embodied in a framework of understanding. We need to study the ontological and epistemological assumptions of selected methods in order to justify their validity and potential to improve our chosen problem environment. Then, we will be able to guide all involved to develop to their full potential to the benefit of themselves and society.

Author Contributions: In terms of author contribution, R.G. was responsible for the conceptualization of the paper, while E.T. was responsible for the literature investigation. The paper was jointly written and reworked.

Funding: This research received no external funding.

Conflicts of Interest: The authors declare no conflicts of interest. 


\section{References}

1. Myers, M.D.; Klein, H.K. A set of principles for conducting critical research in information systems. MIS Q. 2011, 35, 17-36. [CrossRef]

2. Rowe, F. Toward a richer diversity of genres in information systems research: New categorization and guidelines. Eur. J. Inf. Syst. 2012, 21, 469-478. [CrossRef]

3. Myers, M. Qualitative Research in Information Systems. MIS Q. 1997, 21, 241. [CrossRef]

4. Puhakainen, P.; Siponen, M. Improving employees' compliance through information systems security training: An action research study. MIS Q. 2010, 34, 757-778. [CrossRef]

5. Gibbs, P.; Cartney, P.; Wilkinson, K.; Parkinson, J.; Cunningham, S.; James-Reynolds, C.; Zoubir, T.; Brown, V.; Barter, P.; Sumner, P.; et al. Literature review on the use of action research in higher education. Educ. Act. Res. 2017, 25, 3-22. [CrossRef]

6. Baskerville, R.L.; Wood-Harper, A.T. A Critical Perspective on Action Research as a Method for Information Systems Research. In Enacting Research Methods in Information Systems: Volume 2; Springer: Berlin, Germany, 2016; pp. 169-190.

7. Habermas, J. Theory and Practice. London: Heinemann; Heinemann: London, UK, 1974.

8. McNiff, J. Action Research: Principles and Practice; Routledge: Abingdon, UK, 2013.

9. Carr, W.; Kemmis, S. Becoming Critical: Knowing through Action Research; Deakin University: Victoria, Australia, 1983.

10. McTaggart, R. Principles for Participatory Action Research. Adult Educ. Q. 1991, 41, 168-187. [CrossRef]

11. Harvey, L. Critical Social Research; Unwim Hyman: London, UK, 1990.

12. Carr, W.; Kemmis, S. Becoming Critical: Education Knowledge and Action Research; Taylor \& Francis: Milton Park, Didcot, UK, 2003.

13. Bradbury-Huang, H. What Is Good Action Research? Why the Resurgent Interest? Action Res. 2010, 8, 93-109. [CrossRef]

14. Baskerville, R.L. Investigating Information Systems with Action Research. Commun. Assoc. Inf. Syst. 1999, 2, 19. [CrossRef]

15. Susman, G.I.; Evered, R.D. An Assessment of the Scientific Merits of Action Research. Adm. Sci. Q. 1978, 23, 582. [CrossRef]

16. Lewin, K. Frontiers in Group Dynamics: II. Channels of Group Life; Social Planning and Action Research. Hum. Relat. 1947, 1, 143-153. [CrossRef]

17. Avison, D.; Lau, F.; Myers, M.; Nielsen, P.A. Action Research. Commun. ACM 1999, 42, 94-97. [CrossRef]

18. Lau, F. Toward a Framework for Action Research in Information Systems Studies. Inf. Technol. People 1999, 12, 148-176. [CrossRef]

19. McKay, J.; Marshall, P. The Dual Imperatives of Action Research. Inf. Technol. People 2001, 14, 46-59. [CrossRef]

20. Chiasson, M.; Germonprez, M.; Mathiassen, L. Pluralist Action Research: A Review of the Information Systems Literature. Inf. Syst. J. 2009, 19, 31-54. [CrossRef]

21. Kock, N.; Gallivan, M.J.; DeLuca, D. Furthering Information Systems Action Research: A Post-Positivist Synthesis of Four Dialectics. J. Assoc. Inf. Syst. 2008, 9, 48. [CrossRef]

22. Holgersson, S.; Melin, U. Pragmatic Dilemmas in Action Research: Doing Action Research with or without the Approval of Top Management? Syst. Pract. Act. Res. 2015, 28, 1-17. [CrossRef]

23. Amber, Y.G. Using Ict for Social Good: Cultural Identity Restoration through Emancipatory Pedagogy. Inf. Syst. J. 2017, 28, 304-358.

24. Myers, M.D.; Venable, J.R. A Set of Ethical Principles for Design Science Research in Information Systems. Inf. Manag. 2014, 51, 801-809. [CrossRef]

25. Wohlin, C.; Aybüke, A. Towards a Decision-Making Structure for Selecting a Research Design in Empirical Software Engineering. Empir. Softw. Eng. 2015, 20, 1427-1455. [CrossRef]

26. Bassey, M. Case Study Research in Educational Settings; McGraw-Hill Education: New York, NY, USA, 1999. 
27. Johnson, A.P. A Short Guide to Action Research; Pearson/Allyn and Bacon Boston: New York, NY, USA, 2005.

28. Mills, G.E. Action Research: A Guide for the Teacher Researcher; Merrill Prentice Hall: Upper Saddle River, NJ, USA, 2003.

29. Kemmis, S.; McTaggart, R.; Nixon, R. The Action Research Planner: Doing Critical Participatory Action Research; Springer Science \& Business Media: Berlin, Germany, 2013.

30. Battiste, M. Decolonizing Education: Nourishing the Learning Spirit; Purich Publishing: Sascatoon, SK, Canada, 2013; p. 116.

31. Jackson, M.C. Systems Thinking: Creative Holism for Managers; Wiley: Chichester, UK, 2003.

32. Zambo, D. Theory in the Service of Practice: Theories in Action Research Dissertations Written by Students in Education Doctorate Programs. Educ. Action Res. 2014, 22, 505-517. [CrossRef]

33. Reason, P.; Bradbury, H. Handbook of Action Research: Participative Inquiry and Practice; SAGE Publications: Thousand Oaks, CA, USA, 2001.

34. Kemmis, S. Critical Theory and Participatory Action Research. In The Sage Handbook of Action Research: Participative Inquiry and Practice; Reason, P., Bradbury, H., Eds.; Sage: London, UK, 2008; pp. 121-138.

35. Ulrich, W. Critical Heuristics of Social Planning: A New Approach to Practical Philosophy; Wiley: New York, NY, USA, 1983.

36. Schön, D.A. The Reflective Practitioner: How Professionals Think in Action; Routledge: Abingdon, UK, 1983; Volume 5126.

37. Kapenieks, J. Educational Action Research to Achieve the Essential Competencies of the Future. J. Teach. Educ. Sustain. 2016, 18, 95-110. [CrossRef]

38. Dewey, J. Education and Democracy; Macmillan: New York, NY, USA, 1916.

39. Jakovljevic, M.; Ankiewicz, P. Project-Based Pedagogy for the Facilitation of Webpage Design. Int. J. Technol. Des. Educ. 2016, 26, 225-242. [CrossRef]

40. Jeffrey, L.; Hegarty, B.; Kelly, O.; Penman, M.; Coburn, D.; McDonald, J. Developing Digital Information Literacy in Higher Education: Obstacles and Supports. J. Inf. Technol. Educ. Res. 2011, 10, 383-413. [CrossRef]

41. Hegarty, B.; Penman, M.; Brown, C.; Coburn, D.; Gower, B.; Kelly, O.; Sherson, G.; Suddaby, G.; Moore, M. Approaches and Implications of Elearning Adoption in Relation to Academic Staff Efficacy and Working Practice Final Report; Ministry of Education: Wellington, New Zealand, 2005.

42. Adesemowo, A.K.; Johannes, H.; Goldstone, S.; Terblanche, K. The Experience of Introducing Secure E-Assessment in a South African University First-Year Foundational Ict Networking Course. Afr. Educ. Rev. 2016, 13, 67-86. [CrossRef]

43. Cochrane, T.D. Beyond the Yellow Brick Road: Mobile Web 2.0 Informing a New Institutional E-Learning Strategy. Australas. J. Educ. Technol. 2011, 26. [CrossRef]

44. Cuhadar, C.; Abdullah, K.U.Z.U. Improving Interaction through Blogs in a Constructivist Learning Environment. Turk. Online J. Distance Educ. 2010, 11, 134-161.

45. Esteves, M.; Fonseca, B.; Morgado, L.; Martins, P. Improving Teaching and Learning of Computer Programming through the Use of the Second Life Virtual World. Br. J. Educ. Technol. 2011, 42, 624-637. [CrossRef]

46. Isaias, P.; Issa, T. Promoting Communication Skills for Information Systems Students in Australian and Portuguese Higher Education: Action Research Study. Educ. Inf. Technol. 2014, 19, 841-861. [CrossRef]

47. Checkland, P.; Holwell, S. Information, Systems and Information Systems: Making Sense of the Field; Wiley: Chichester, UK, 1998.

48. Churchman, C.W. The Systems Approach; Dell Publishing: New York, NY, USA, 1968.

49. Latour, B. Network Theory Networks, Societies, Spheres: Reflections of an Actor-Network Theorist. Int. J. Commun. 2011, 5, 15.

50. Giddens, A. The Constitution of Society: Outline of the Theory of Structuration; University of California Press: Berkeley, CA, USA, 1984.

51. Basden, A. Philosophical Frameworks for Understanding Information Systems; IGI Global: Harrisburg, PA, USA, 2007.

52. Dooyeweerd, H. Roots of Western Culture: Pagan, Secular, and Christian Options; Wedge at Foundation: Asheville, NC, USA, 1979.

53. Ackoff, R.L. Redesigning the Future: A Systems Approach to Societal Problems; Wiley: New York, NY, USA, 1974. 
54. Thomas, J.W. A Review of Research on Project-Based Learning. Available online: http://www.bie.org/index. php/site/RE/pbl_research/29 (accessed on 6 July 2019).

55. Helle, L.; Tynjälä, P.; Olkinuora, E. Project-Based Learning in Post-Secondary Education - Theory, Practice and Rubber Sling Shots. High. Educ. 2006, 51, 287-314. [CrossRef]

(C) 2019 by the authors. Licensee MDPI, Basel, Switzerland. This article is an open access article distributed under the terms and conditions of the Creative Commons Attribution (CC BY) license (http://creativecommons.org/licenses/by/4.0/). 